\title{
The Exploration on the Cultivation of
}

\section{Comprehensive Ability in Full-time Masters Related to Maritime Affairs Based on the Integration of Production and Teaching}

\author{
Jiakuo Zhang \\ Zhe Jiang Ocean University \\ School of Port and Transportation Engineering \\ Zhou Shan, China \\ E-mail: 2605484926@qq.com
}

\author{
Wenfeng Wu*, Jinshu Lu, Jianwei Zhang, Faxin Zhu \\ Zhe Jiang Ocean University \\ School of Port and Transportation Engineering \\ Zhou Shan, China \\ E-mail: wuwenfeng0611@126.com
}

\begin{abstract}
The training of full-time professional degree postgraduates has become a new requirement for the development of high-level applied talents in economic and social development in China. Taking Zhe Jiang Ocean University fulltime professional master as an example, this paper analyses the necessity and function for the training of professional master's degree postgraduates based on the mode of integration of production and teaching, probes into the problems existing in the training of applied talents in Colleges and universities at present, and formulates feasible cultivation countermeasures including the aspects of setting up a reasonable curriculum system, making full use of practice bases, introducing related projects and cultivation of double tutors. It provides reference experience for the establishment of training mode oriented to enhance professional competence, the cultivation of professional master's practical innovation ability, and the improvement of employment rate.
\end{abstract}

Keywords-integration of Production and Teaching; full-time professional masters; the comprehensive ability; countermeasure

\section{INTRODUCTION}

With the increase of the demand for high academic background and professional ability talents in the society, it is necessary for colleges and universities to cultivate full-time professional masters with high professional accomplishment and practical ability to meet the needs of economic development. At the end of 2017, the General Office of the State Council issued a document entitled "Several opinions on deepening the Integration of Production and Teaching" raising it to the development of the national education reform and personnel training, and constructing a "four-in-one" pattern of integration of production and teaching. At the same time, it is beneficial to adjust the structure of personnel training and speed up the construction of high-level universities so as to promote the integration of production and teaching towards a new stage[1].

The integration of production and education is not only suitable for the application-oriented universities, but also for the research universities[2]. With the increasing recognition of

Fund Project: General Research Project of Zhe Jiang Education Department and Graduate Education Society Project, Project: No.Y201840547 full-time professional master by the society, the training mode has also exposed some defects, which are manifested in a single content, inaccurate positioning and serious formalism. In addition, full-time professional masters also need to improve the practical ability and professional quality. Therefore, the establishment of a high-level innovation and applicationoriented personnel training mode, which is oriented to the improvement of professional ability, has become the focus of research and reform in the field of professional degree education in the new era. In order to cultivate high-level fulltime professional masters, Zhe Jiang Ocean University is committed to relying on the ocean, serving the local areas, combining marine industry and teaching through the mechanism of integration of production and teaching, and jointly cultivating professional talents in the new period.

\section{Problems In the Training OF FUlL-TIME Professional MASTERS}

In China, a number of full-time professional graduates are increasing year by year. Taking Zhe Jiang Ocean University as an example, the degree system of full-time masters in 2017 is two years, and in 2019 is changed to three-year. In 2017, a total of 218 full-time professional masters were recruited, including 70 masters of engineering and 218 masters of agriculture, and in 2018, the number rose to 326 full-time masters, including 70 masters of engineering and 256 masters of agriculture. When time comes to 2019, the Zhe Jiang Ocean University adds Master of education, pharmacy and tourism management, which is expected to increase the enrollment of full-time professional masters to around $40 \%$. With the increase of fulltime professional masters, it has become an indispensable part of regional economic development to find the training orientation of professional masters, improve the comprehensive practical ability of graduates, and improve the quality of education and human resources so as to make the school develop better.

\section{A. The insufficient guiding role in local government}

Local municipal governments issued the teaching reform documents on deepening vocational education and 
comprehensively improving the quality of personnel training, requiring universities and enterprises to integrate their own resources and cooperate in training high-level and high-quality talents in the new era. However, the local governments have not elaborated specific implementation standards and substantive reforms. Furthermore, the establishment of enterprise joint training bases needs a lot of financial to support But governments can provide limited funds for the construction of supporting facilities, which some expenditure need investment from enterprises and the short-term return rate of enterprises is low. Accordingly, the reasons result in the low enthusiasm of enterprises to participate and reluctance to cultivate professional talents with universities.

\section{B. The orientation of college training programs is not clear}

The postgraduate education system in China is still not perfect, which mainly reflected in the low enthusiasm for local economic development. Some graduate schools have such problems. First, the training scheme of professional master is similar to that of academic degree, such as curriculum arrangement and subject selection requirements. Most of the tutors of professional masters can guide several academic masters. Basically, they regarded the professional masters as full-time academic postgraduate training. It is commonly believed that the training of full-time academic masters should focus on theoretical scientific research and professional masters, on the contrary, should focus on engineering practice to solve practical problems[3].

Second, the professional postgraduate training program stipulates that the off-campus practice teaching task must be guaranteed to be no less than 6 months. Colleges and universities do not strictly regulate the content of off-campus training and lack of rigorous teaching methods in process of practice. For students, they have no specific goals and plans beforehand, lack of technical exchanges with external tutors, and whose theoretical learning time cannot be guaranteed, so that lead to the lack of pertinence and effectiveness of the professional talents training program.

\section{Poor execution of the dual tutor system}

The criteria for selecting talents in enterprises are often to judge the practice, innovation ability and professional accomplishment of the person. Although many colleges and universities in China implement the dual tutorial system, most of the off-campus tutors do not participate in the guidance of graduate students. The dual tutorial system mainly faces two problems. On the one hand, there are few engineers with senior professional titles in enterprises, and fewer tutors who can guide graduate students systematically. On the other hand, many university master tutors have their own scientific research background and profound theoretical knowledge in the field of disciplines, but lack of engineering practice experience, thus they can't give effective off-campus practical guidance to postgraduates. Moreover, many students complete their master's thesis based on the existing projects of the tutors, which are rooted in the Laboratory for physical experiments and simulation[4]. In addition, as for off-campus cooperative enterprises, they are afraid of the students lacking of practical experience, neglecting the production process, thereby delaying the production task, and for safety reasons, they are not willing to let postgraduates participate teaching, so the practical teaching links cannot be fully and effectively implemented.

It is precisely because of the above problems that the quality of professional training is generally not high, and the employment competitiveness is not strong. Therefore, not only colleges and universities should attach importance to the innovation ability and practical ability, but also improve the comprehensive practical ability of full-time professional masters. Meanwhile, they shall strengthen close cooperation with enterprises and achieve complementary development between schools and enterprises.

\section{COUNTERMEASURE OF FULL-TIME PROFESSIONAL MASTER TRAINING MODEL}

The key to the comprehensive ability training of full-time professional masters is to cultivate innovative ability and professional ability.

\section{A. Reasonable curriculum system and practice links}

By undertaking the integration project of production and teaching, the university will introduce the advanced scientific research technology and technical knowledge of the enterprise into the classroom teaching, reduce the number of unrelated courses, introduce advanced technical courses of schoolenterprise cooperation, increase the quantity of engineers teaching, so that improve the quality of practical teaching. Both intramural and extramural academic advisor should pay attention to the combination of theory and actual production, combining advanced technology with traditional technology, For professional postgraduates, they can make up for shortcomings in the practice teaching of the enterprise through systemic learning in the school curriculum. At present, Zhe Jiang Ocean University has developed a rigorous practice teaching assessment method and a characteristic curriculum system in the training of full-time professional masters, including adding 6 credits in the practice teaching link, which is from June of the second semester to June of the next year. Finally, the professional masters are required to complete the practice summary report with high quality and submit it to the supervisor for assessment. Through the three learning forms of "combination of teaching and practice, performance and assessment, innovation and skills", the quality of teaching will be improved, and the talent training program will be truly implemented in practice. What can be seen that through the discussion, study, thinking, analysis and summary of the whole practice link, students can better integrate into the enterprise environment and improve their comprehensive practical ability efficiently.

\section{B. Make full use of the research and development platform of school-enterprise practical engineering base}

At present, Zhe Jiang Ocean University has developed a good mode of integration of production and teaching. The school has three national disciplinary platforms, including the National Research Center of Marine Facility Aquaculture Engineering Technology, the National Local Joint Engineering Laboratory and the National Local Joint Engineering Laboratory of Oil and Gas Storage and Transportation Technology. Moreover, it also has 25 provincial and ministerial disciplines platforms such as Zhe Jiang Joint Key Laboratory 
of Aquatic Products Processing Technology and Zhe Jiang Key Laboratory of Offshore Marine Engineering Technology, as well as 33 postgraduate production practice and practical comprehensive education bases. In 2017, the University Science and Technology Park of Zhe Jiang Ocean University completed preparatory work, park planning and building construction tracking, actively carried out reporting and communication with provincial science and technology department and education department, carried out the recruitment work of enterprises entering the park. There are more than 70 enterprises in Zhe Jiang Ocean University Entrepreneurship Park, which have done a good job in combing, docking and screening of enterprises. In 2018, Ding Hai Research Institute solved technical problems for enterprises, trained high-tech enterprises, actively introduced famous universities, carried out multi-faceted, multi-level and all-round exchanges and cooperated with China Shipping Heavy Industry 716 Research Institute, Shanghai Laser Technology Research Institute and Bei Hang Research Institutions. In short, numerous joint training units of schools and enterprises have strongly supported the training of full-time professional postgraduates in our university. Schools and enterprises jointly invest funds to train high-level professional talents, and enable students to serve enterprises, this pattern also promotes the rapid development of universities and enterprises, and greatly improves the ability of professional graduates to innovate and solve practical problems in engineering.

\section{Introducing Practice Teaching into Project to Promote the Joint Training of Double Tutors}

Cooperation is the premise of mutual benefit, if universities and enterprises want long-term and cooperate to development steadily, they should reinforce in cooperation, and introduce common project. Zhe Jiang Ocean University has cooperated with local enterprises to undertake large key scientific research projects. The project mainly covers ship manufacturing, intelligent ship system development, aquaculture, fishery facilities and intermodal transport engineering and other fields. As for professional postgraduates, we can divide it into two main phases, in the first academic year; it is focus on learning theoretical knowledge and familiarizing with scientific research projects step by step as to strengthen the innovative ability and theoretical literacy of postgraduates. In the second academic year, the training mode mainly focuses on the off-campus training stage and the writing stage of master's thesis, which aim to enable students to integrate into the society, improve practical ability and solve problems independently.

However, the integration of production and teaching projects depends not only on the development of students' research and innovation capabilities, but also on the guidance of graduate tutors. The in-school tutor of the graduate student is served by the teacher with the background of professional engineering theory, and the out-of-school tutor is appointed by the university with strong practical ability and strong sense of responsibility, and has the senior professional title as an engineer. In-school tutors are specifically responsible for assisting graduate students in formulating personal training programs, curriculum arrangements, topic selection guidance, off-campus practice and other work of supervision. Out-ofschool tutors are responsible for students' practical teaching, technical guidance, research and design, production safety and other aspects of the work. By jointly selecting tutors from universities and enterprises to participate in the thesis guidance of full-time professional master, we can't only achieve complementary advantages, but also close the gap between students, society and enterprises, which greatly stimulates the learning enthusiasm of full-time professional master students and builds up good self-confidence[5].

\section{Constructing the Training Model of Industrialized Talents and Emphasizing the Cultivation of Comprehensive Ability}

The purpose of talent training is to serve the development of local enterprises. When universities and enterprises jointly train professional degree masters, the emphasis should be placed on the promotion of professional ability, the main line of which is comprehensive quality and practical ability, and construct the "industry and teaching, Theory and practice, scientific research and practice," trinity training model. When a professional postgraduate enters an enterprise or a joint training base for practice, they often face problems such as production process, product development, optimization, implementation and re-optimization, which are difficult to come into contact with in teaching. Therefore, in the initial stage of practice, it is necessary to collect information about production links of practice enterprises, understand enterprise information, and familiarize with enterprise processes, use knowledge and technology to analyze, infer and solve practical problems. The whole process of practice should be diligent in learning, thinking, rigorous and efficient. As a result, it is particularly important to cultivate the comprehensive ability of professional master to deal with problems. The participation of the whole link can help graduate students develop the thinking ability of being inquisitive and good at thinking [6]. The practice process is shown in Fig. 1.

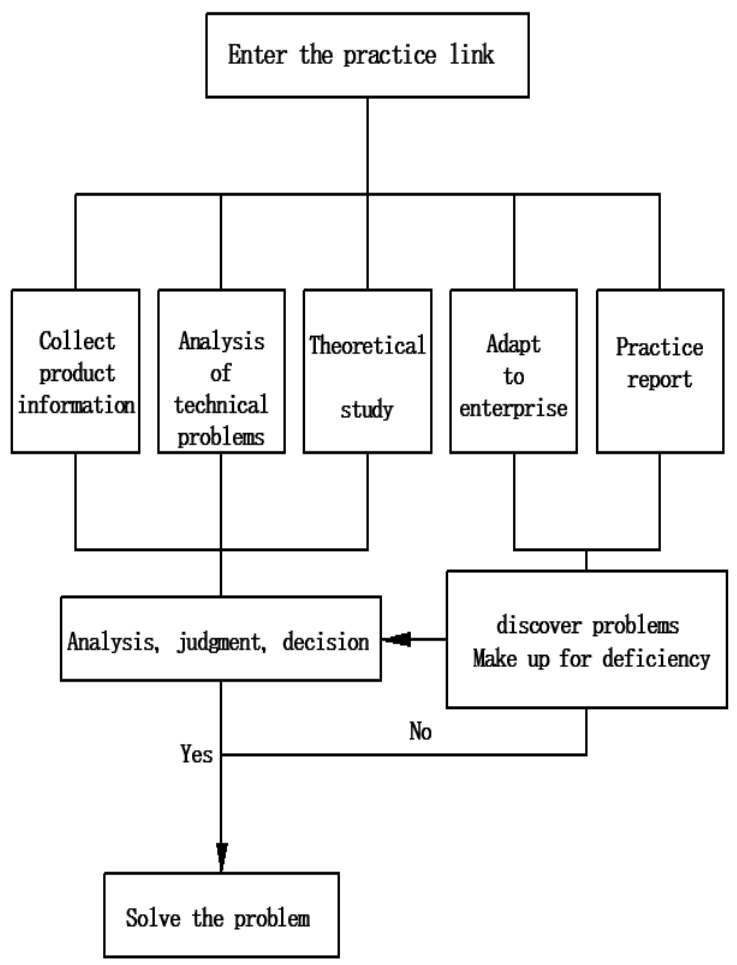

Fig. 1. Practice process 


\section{CONCLUSION}

Zhe Jiang Ocean University attaches importance to strengthening the development of local industries as its foundation and training high-quality professionals as its orientation. Through adopting diversified forms, it strengthens the cooperative development with local ship, aquatic products, enterprise research institutes, and continues to deepen the cooperation between schools and enterprises, the concept of combining work with study, and continuously improves the comprehensive ability of professional degree postgraduates.

In short, in order to meet the requirements of local economic development and technological progress, promote regional economic development, and fill the vacancy of highlevel and high-level talents in China, it is the background of integration of industry and teaching that the cultivation mechanism of the comprehensive practical ability of full-time professional master related to Maritime Affairs can effectively combine the theoretical study with the engineering practice outside the school, so as to improve the undefined ability of solving problems and comprehensive practical ability of engineering. It conforms to the inherent law of higher education development and promotes the long-term stable and cooperative development of local universities and enterprises.

\section{REFERENCES}

[1] Jia Liang. "Reform and Practice of Innovative Talents Training in Underground and Tunnel Engineering Technology Based on Integration of Industry and Education-Taking Shaanxi Railway Engineering Vocational and Technical College as an Example,"[J]. Shanxi Education (Higher Education), 2018(08):35-36. (In Chinese)

[2] Chen Feng. "Seize the opportunity, take advantage of the momentum, and promote the integration of industry and education to a new stage," [J]. China Higher Education, 2018(02):18-22.(In Chinese)

[3] Shi Weilin, Hui Wenjie. "Is the Dual Supervision More Effective to Improve the Occupational Ability of the Full-time Professional Master Students,” [J] China Higher Education Research, 2018(10):68-74. (In Chinese)

[4] Wang Ming, Zhou Huanfu, Long Fei. "Practice of Creative Ability Promotion of Materials Engineering Professional Master by IndustryAcademia-Research Mode,” [J] Higher Education Forum, 2015(07):969.(In Chinese)

[5] Lin Meibin, Li Bin. "Research and Practice on the Cultivation of Innovative Practical Ability of Full-time Professional Degree Postgraduates Based on the Combination of Industry, Education and Research"[J].Industry and Information Technology Education, 2014(01):79-82.(In Chinese)

[6] Chen Chen,Chen Ting,Tian Yuan and Xie Weifang. "Analysis the Role of School-enterprise Cooperation Platform on the Cultivation of Postgraduates Innovation Ability," $[\mathrm{J}]$ China Modern Educational Equipment, 2017(01):87-90.(In Chinese) 